\title{
Translanguaging Practices of Multilingual Learners of German
}

\author{
By Annabell Sahr
}

\begin{abstract}
This qualitative case study draws on a theoretical framework of translanguaging (García \& Wei, 2014) and border pedagogies (Cashman, 2015) and seeks to shed light on the question of what role translanguaging can play in students' language learning in a German as a foreign language class at a Hispanic-serving university that is situated in the United States-Mexico borderland. This case study focuses on 18 students who were part of a larger participatory action research study (Lichtman, 2013), which includes focus groups, individual interviews, as well as audio-recordings of classroom discussions that were transcribed and analyzed using thematic analysis. The data highlights translanguaging as a language learning practice that also contributes to reflections on identity formation and language choice in an educational climate that is often hostile towards immigrant cultures and languages.
\end{abstract}

Keywords: bilingual, German language, instruction, translanguaging.

\section{Introduction}

The number of bilingual students in the United States is continuously rising. From currently 37 million speakers it is projected to grow to 40 million by 2020 (Lopez, 2013). Moreover, the U.S. Department of Education National Center for Education Statistics (2015) states that the number of English language learners has been increasing, and $15.5 \%$ of the public-school students in Texas were English language learners during the 2014/2015 school year. Yet a review of secondary level curricula for German as a foreign language produced by American textbook companies illustrates that textbooks and teaching materials for German are written assuming students to be monolingual English speakers (U.S. Department of Education, 2015). Textbook publishers that focus on an American audience and produce German curriculum for college level German classes include McGrawHill and Pearson. All German textbooks available from these publishers use a communicative approach to teaching German as a first foreign language (Gonglewski, 2013; Di Donato, 2004; Tschirner, 2017). Bilingual students bring untapped potential to the classroom, which is not recognized by textbooks or considered in research on German learning in the United States.

The study takes place at a borderland university, with a student body of about 80\% Hispanics (UTEP, 2017) in a town that has made the news for a testing scandal in which bilingual and immigrant children were prohibited to participate in high-stakes state testing or were pushed out of the educational system altogether;

*Lecturer, University of Texas at El Paso, USA. 
being bilingual was framed as a problem (Reyes, 2016). Overall in the German as a foreign language class the bilingual or multilingual students do not see themselves represented because the curriculum and the textbooks seem to assume that only monolingual English-speakers learn German, which overlooks the linguistic repertoire of multilingual students. It leads to the question of who is represented (monolingual English speakers) and who is absent from both research and the curriculum (low-income bilingual students). The context of this study is an environment with very dominant discourses that frame bilinguals as having language deficits (Reyes, 2016). Moreover, assimilationist discourses, essentializing discourses and normalizing discourses of whiteness (Abraham, 2014) are being internalized by students and become authoritative discourses that guide students' behavior and language choices. Translanguaging is originally a pedagogical practice from bilingual schools in Wales and originated from the Welsh word for trawsieithu referring to having "input in one language and conducting a task in another language" (Cenoz \& Gorter, 2011, p. 341). Translanguaging as an approach considers the different languages that a bilingual or multilingual person speaks as one linguistic repertoire (García \& Wei, 2014) and views a bilingual person as more than just a combination of two monolinguals (Grosjean, 2010). García explains translanguaging as "multiple discursive practices in which bilinguals engage in order to make sense of their bilingual worlds," which is the norm in bilingual communities (García \& Wei, 2014, p. 22). García \& Sylvan (2011) also theorize translanguaging as "a product of border thinking, of knowledge that is autochthonous and conceived from a bilingual, not monolingual, position" (p. 389). Creese and Blackledge (2010) argue for translanguaging as bilingual pedagogy and state that translanguaging (García, 2007) and heteroglossia (Bakhtin, 1981) serve "to describe language fluidity and movement" (Creese \& Blackledge, 2010, p.112). Translanguaging can be perceived as a heteroglossic practice and pedagogy for social justice (García \& Leiva, 2014, p. 204). When using translanguaging practices in the classroom, students' epistemological frameworks might change along with what they believe to be true about a language.

This study tries to facilitate a learning process in which students gain a higher level of consciousness (Freire, 1970) about languages which contributes to positive multilingual identity development. The research focuses on the role of translanguaging in the German language classroom.

\section{Literature Review}

Current research on German learning in the United States focuses on monolingual students (Bartolotti \& Marian, 2017; Belz \& Reinhardt, 2004; Scheutz \& Eberhard, 2004; Schmid, 2014; Abrams, 2016; de Oliveira Santos, 2015; Neville, Shelton, \& McInnis, 2009; Dixon \& Hondo, 2013). Bilingual identity is only explored in a few research studies that focus on German instructors-the biliteracy of students is not considered (Aslan, 2015; Ghanem, 2015; Weninger, 2007). The current approach of focusing on monolingual learners 
of German leads to the problem that bilingual student populations are underrepresented in the available research in the United States. As Grenfell and Harris (2015) point out there is research in the field of third language acquisition, but little research on German as a third language particularly outside of Europe (Grenfell \& Harris, 2015). While it has been established that a second language influences the learning process of a third language as much as a first language, and that there is a growing number of bilingual students in the United States, German as a third language has not been studied widely (Falk \& Bardel, 2010). Although research on third language learning is available in the United States it does not focus on German (Bono \& Stratilaki, 2009; Cenoz \& Gorter, 2011; De Angelis, 2007; De Angelis, 2011; Jaensch, 2011; Jessner, 2008; Rothman, Iverson, \& Jurdy, 2010), but mostly on cognitive language learning (Bartolotti \& Marian, 2017; Scheutz \& Eberhard, 2004; Schmid, 2014), isolated language learning strategies (Abrams, 2016; de Oliveira Santos, 2015; Neville, Shelton, \& McInnis, 2009; Dixon \& Hondo, 2014) or German instructors (Aslan, 2015; Ghanem, 2015; Weninger, 2007). Cross-cultural differences have also been studied. For example one study focuses on cross-cultural differences between Spanish and German bilinguals who when tested in Spanish scored higher on extraversion and neuroticism while they scored high on agreeability when tested in German (Veltkamp, Recio, Jacobs, \& Conrad, 2012). It can be observed that those studies that focus on German language learning in the United States only have monolingual English-speaking students as participants who are learning German (Dixon \& Hondo, 2013; Jackson, 2007; Neville, Shelton, \& McInnis, 2009). The available research on multilingualism points out that the students' languages are only useful resources for learning a new language if they are allowed in the classroom and if they are part of how the teacher teaches the new language. Furthermore, a teacher must be able to facilitate the relationships between previous languages and a new language (Jessner, 2008; Grenfell \& Harris, 2015).

The use of English is associated with being at the core of what constitutes being an American according to the dominant discourse, which can be described as the one nation, one language ideology (Hansen-Thomas, 2007; Hornberger, 2002). Students who might happen to speak other home languages will try to subscribe to this dominant discourse and adopt English language practices for their communicative purposes while in the university setting, because they tend to be aware of the cultural capital of English versus their home dialects or home languages (Ullman, 2012). Language ideologies are very powerful (Schieffelin, Woolard, \& Kroskrity, 1998; Woolard, 1992). They are defined as the "beliefs, ideas amd values that exist as systems binding communities together" (Razfar \& Rumenapp, 2012, p. 348). The beliefs about languages become revealed as well as reproduced through cultural practices (Razfar \& Rumenapp, 2012). Language ideologies are representing "ideas of power and identity as constructed by a society" (Razfar \& Rumenapp, 2012, p. 349). Language hegemony and the domination of ideologies are backed up by policies and politics, this hegemony can be observed in classrooms as well, because "power structures are inherent in every instance of language use" (Razfar \& Rumenapp, 2012, p. 349). Classroom discourse is mediating interactions. "Making language ideologies explicit opens 
the classroom as a site where teachers and students can contest hegemonic symbolic relations and inequitable power structures, and seek transformative change" (Razfar \& Rumenapp, 2012, p. 365). According to Schieffelin, Woolard, \& Kroskrity (1998) language ideologies underpin notions of identity. Language ideologies and identities are closely connected, which is demonstrated for example in a study by Turkan and DaSilva Iddings (2012) who look at English language learners' identities in an era of standardized testing, in which hegemonic ideologies about English guide educational policies (Turkan \& DaSilva Iddings, 2012). Speaking English and being successful in educational settings are discourses that are related to educational policy. The methaphor of speaking English as a success impacts immigrant children's self-identification and conceptions of language according to Turkan \& DaSilva Iddings (2012). Deficit notions for so called non-native language speakers are widespread in educational settings, because emergent bilinguals or multilingual students are measured against monolingual speakers (Cenoz \& Gorter, 2011). Grosjean (2010) has been arguing that the communicative competence of a bilingual person cannot be compared to that of a monolingual. Bilinguals are valued for their multicompetences within a dynamic bilingualism conceptualization (García \& Sylvan, 2011, p.389). García \& Sylvan (2011) also theorize translanguaging as "a product of border thinking, of knowledge that is autochthonous and conceived from a bilingual, not monolingual, position" (García \& Sylvan, 2011, p.389).

While Anzaldúa (1987) differentiates the various languages she speaks in Borderlands/La Frontera as standard English, standard Mexican Spanish, standard Spanish, working class English, North Mexican Spanish dialect, Chicano Spanish with regional variations in Texas, New Mexico, Arizona, and California, Tex-Mex and Pachuco, translanguaging is moving away from the concept of different distinct language systems that exist inside the multilingual person's mind but it maps those as part of one fluid language repertoire. Translanguaging is the lived practice of students around the border (Cervantes-Soon \& Carillo, 2016; Collins \& Cioe-Pena, 2016; Creese \& Blackledge, 2010; Esquinca, Araujo, \& de la Piedra, 2014; García, Homonoff Woodley, Flores, \& Chu, 2012; Lewis, Jones, \& Baker, 2012; Mazak \& Herbas-Donoso, 2015; Melo-Pfeifer, 2015; Ramirez, Ross, \& Jimenez-Silva, 2016; Rios, 2013; Salinas, Vuckery, \& Franquiz, 2016; Velasco \& García, 2014). Speakers effortlessly include both elements of their Spanish and English language repertoire into a conversation, students who are learning an additional language such as German in the case of this study will include German into their available register and make use of Spanish, English and German depending also on the communicative needs of their interlocutor. Translanguaging together with border pedagogy and heteroglossia inform a pedagogical approach for teaching German through which students might be able to deconstruct their language ideologies and the dominant monolingual discourses through a raised consciousness and reflexive practices. Multiple studies in recent years have adopted border pedagogies or the concept of borderland (Cervantes-Soon \& Carrillo, 2016; Cashman, 2015, 2016; Ramirez, Ross, \& Jimenez-Silva, 2016; Reyes, 2016; Rios, 2013; Stewart \& Gachago, 2016). Rios' (2013) study on Chicana students in the borderland applied border pedagogies and specifically 
critical dialogue, which lead to a deconstruction of race and culture in the classroom. Wilson, Ek, Ty, and Douglas (2014) used border crossing pedagogies in order to highlight that Latina/o students were made invisible in their secondary school. In a similar manner, Reyes (2016) gives the case of the El Paso Independent School District corruption scandal as an example for the silencing of Latina/o student voices, who were systematically excluded from high stakes testing or pushed out of the high school system altogether in order to improve the state exam test scores for the district. As Reyes (2016) summarizes the EPISD test cheating scandal in El Paso reflects the complexities of the border identity and education of marginalized Mexican-American students. Moreover, the borderland is rich in discourses and tensions between "nationalism, bilingualism, monolingualism, racism, discrimination, and uniformity" (Reyes, 2016, p. 347). Humanizing aspects of border pedagogies are also demonstrated by Stewart \& Gachago (2016) in a transcontinental border crossing digital storytelling project which results show that through the project notions of otherness were critically demystified, which allows students to counter global hegemonic discourses. In current research activism is also seen as an essential part of border pedagogy (Ramirez, Ross, \& Jimenez-Silva, 2016). In their qualitative study on two U.S. Latina teachers in a border community in California Ramirez, Ross and JimenezSilva (2016) found that the teachers applied border pedagogy through authentic care/cariño (Valenzuela, 1999), critical consciousness/ concientizacíon (Freire, 1970), and community activism (Ramirez, Ross, \& Jimenez-Silva, 2016, p. 318). Ramirez, Ross and Jimenez-Silva (2016) in their theoretical framework for their study draw on nepantla (Anzaldúa, 1987) as a place where the transformation of identities can take place. Through the enactment of border pedagogy students developed critical consciousness together with their teachers in this nepantla space (Ramirez, Ross, \& Jimenez-Silva, 2016, p. 304). In a similar qualitative case study with one focal teacher education candidate observing one high school student labeled as having limited English language skills, LatCrit was used in order to deconstruct majoritarian tales of what it means to be a citizen in the United States (Salinas, Vuckery, \& Franquiz, 2016). The findings indicate that the student teacher's prior assumptions could be transformed, and Latina/o students could challenge dominant discourses by using mestiza consciousness (Anzaldúa, 1987). In an ethnographic study that took place in the academic year of 2009 and 2010 at Preparatoria Altavista in Juárez, Mexico, Cervantes-Soon observed 10 female students in and outside the classroom, interviewed students and teachers. This ethnographic work together with a theoretical framework building on border thinking Mestiz@ theories of intelligence (Carrillo, 2013), and Chicana feminist thought (Anzaldúa, 1987) informed three decolonizing border pedagogy practices for border thinking that Cervantes-Soon and Carrillo (2016) propose: straddling, translanguaging and testimonio (p.288). Cervantes-Soon and Carrillo (2016) connected cultural capital, border pedagogy and translanguaging. They explain that while students need to be aware of the cultural capital of the dominant world, they propose translanguaging, which they see closely related to border crossing and as an essential part of border pedagogy as a way to overcome an Anglophone monolingualism, and a deficit view of bilingualism, and at the same time 
overcome a negative view of border variances of Spanish (Cervantes-Soon \& Carrillo, 2016; Zentella, 2007).Translanguaging, through their dialogic border pedagogy praxis orientation (Cashman, 2016) is described as a heteroglossic practice for social justice. This notion is in sync with García's theorizing of translanguaging as a heteroglossic practice and pedagogy for social justice.

\section{Methodology}

A qualitative case study seems appropriate to shed light on the question of how multilingual students make sense of learning German through their language choices at a borderland university. As a language educator, I create translanguaging spaces and use authentic care/cariño (Valenzuela, 1999), critical consciousness/ concientizacion (Freire, 1970), and community activism (Ramirez, Ross, \& Jimenez-Silva, 2016, p. 318) in my classroom. The borderland community in El Paso is a widely bilingual one. Where you can never make assumptions about who speaks Spanish and who does not. Speaking English is clearly connected with "Americanness" and whiteness. The examples from the classroom show that students who self-identify as bilingual in Spanish and English and as Mexican prefer to speak in either or language and have negative sentiments towards mixing both.

I value and embrace students' histories and linguistic resources and see myself as a facilitator of learning in the classroom (García, Homonoff Woodley, Flores \& Chu, 2012). García, Ibarra Johnson and Seltzer (2017) highlight that a translanguaging classroom is strategic and purposeful in setting up a "powerful, equitable learning environment" (p.16) which enables students "to (1) engage with complex content and texts, (2) strengthen linguistic practices for academic contexts, (3) draw on their bilingualism and ways of knowing, and (4) develop socioemotionally with strong bilingual identities" (p.16). If teachers manage to set up their classroom effectively according to these guidelines, they can advance social justice (García \& Ibarra Johnson \& Seltzer, 2017, p. 16).

This study will add to the theory about translanguaging, which so far is centered mostly on Spanish and English in the United States (Esquinca, 2013; Esquinca, Araujo, \& de la Piedra, 2014; García, 2014; García, 2009; García \& Sylvan, 2011; García \& Wei, 2014; García, Homonoff Woodley, Flores, \& Chu, 2012; Sembiante, 2016). The primary data for this study includes audio-recordings of every German class-session in the 2018 spring semester at a borderland university in the Southwest of the United States. Furthermore, the 19 participants of this case study took part in a series of three phenomenological interviews (Seidman, 2013). Three different sections of German are part of this study at two different language levels, German one and German two. German one is a class for beginners. Some of the participants in the German one class had some prior knowledge of German either through previous classes taken in high school or through family members, the majority had no prior knowledge of German. The German two classes are geared towards advanced beginners who have prior knowledge of grammatical structures and have the comprehension skills and 
vocabulary skills to hold a short conversation about a familiar topic in German. The German one course has 21 participants while the two German two courses have 11 and 12 participants respectively.

\section{Participants of the Study}

The 44 participants of the main study in the three sections of German used different language combinations: English-German and Spanish-German, some participants used all three languages for their interactions in class depending on the communicative need of the interlocutor. All participants completed the series of three phenomenological interviews. During the second interview all 44 participants were asked how they self-identify and the following categories emerged: 16 said they identify as American and 14 identified as Mexican. 11of the students identified as Mexican-Americans or Hispanic or Latina/o and three identified as Chicana/o. For this case study I focused on representative cases from each of the groups, yielding a total of 19 participants (18 students and myself as the instructor) who are included in this case study. Those participants who identified as Mexican also tended to self-identify as bilingual in English and Spanish, while those who identified as American tended to describe themselves as not bilingual, even though they had familiarity with another language other than English. Of the 16 participants that fall under this category, five either had German heritage or one German parent or were born in Germany and had lived there for a period of time. Some of the participants spoke Spanish at home with family members but did not consider themselves as bilinguals because of their perceived deficits in academic or standard Spanish. All participants chose their own pseudonym for the study.

\section{Data Analysis}

During the spring semester 2018 every German class was audio-recorded and all interactions were transcribed. From all the transcriptions available I chose seven that give examples of typical group work or conversations. The excerpts are selected from all three classes that participated and represent 19 participants. Those participants give perspectives on the different student groups that were represented in the three German classes (Creswell, 2005). Furthermore, all case study participants had completed three phenomenological interviews, in order to gain insight into the students' heritage and language use growing up as well as their language choices in prior educational settings before entering the German class. The series of interviews also served the purpose to member check with participants because they had a chance to see their transcribed interactions from the classes and to provide their feedback on it, which allowed to triangulate the data. All data was analyzed with thematic analysis for emerging themes. 


\section{Findings/Results}

The seven excerpts in this section show examples of classroom interactions of the different participant groups. Excerpts one and two show that multilingual interactions are taking place in the German class. Students identifying as Mexican often used Spanish to discuss content and ask each other questions about the tasks at hand, as excerpts one and two show. The students in both groups self-identified as Mexican and bilingual in Spanish and English. In line 21 and line 23 of excerpt one Claudia addresses me in English to verify her answer, and in line 42 she uses English to answer a question that I had asked the whole class.

During this interaction, the students were working on an activity in the Treffpunkt Deutsch textbook during the German 2 class. The activity focuses on verbs with stem-vowel change, and students have to work together to complete sentences that are projected to the front of the classroom. They are expected to use correctly conjugated verb forms in the sentences. The English translation of German and Spanish is added in the middle column of the table. On the left side of the table is the actual conversation between the two students Claudia and Humberto and me, the teacher. I am walking around the room listening to different groups during this activity. This excerpt is an example of a typical conversation in class. The task that students were working on was two-fold, they first had to find the third person singular conjugation of a verb with stem vowel change and then transform the sentence into the plural form, which required a third person plural conjugation.

$\mathrm{A}=$ Annabell (instructor)
$\mathrm{C}=\mathrm{Claudia}$
$\mathrm{H}=$ Humberto
Spanish is $\underline{\text { underlined in the original utterance and the English translation }}$

Table 1. Excerpt 1 In-class Conversation

\begin{tabular}{|c|c|c|}
\hline Utterance & English Translation & Explanation \\
\hline $1 \mathrm{C}$ : fährt & drives & $\begin{array}{l}\text { Claudia is reassuring herself that her } \\
\text { answer is correct by getting the } \\
\text { teachers attention while conjugating } \\
\text { out loud }\end{array}$ \\
\hline $\begin{array}{l}2 \text { A: Oma Ziegler is third } \\
\text { person singular, ich fahre, } \\
\text { du fährst, er fährt }\end{array}$ & $\begin{array}{l}\text { Grandma Ziegler ... I } \\
\text { drive, you drive, he drives }\end{array}$ & $\begin{array}{l}\text { The teacher gives an explanation and } \\
\text { reassures Claudia that her answer is } \\
\text { correct }\end{array}$ \\
\hline $\begin{array}{l}3 \text { C: Ich fahre, fährst du } \\
\text { einen fahren Sie }\end{array}$ & $\begin{array}{l}\text { I drive, drive you a drive } \\
\text { you (formal) }\end{array}$ & $\begin{array}{l}\text { Claudia conjugates the stem-changing } \\
\text { verb fahren }\end{array}$ \\
\hline $\begin{array}{l}4 \mathrm{H} \text { : Entschuldigung, wo } \\
\text { (Pause } 5 \text { seconds) okay } \\
\text { Entschuldigung wo halts } \\
\text { hier der Bus? }\end{array}$ & $\begin{array}{l}\text { Excuse me, where okay } \\
\text { excuse me where does the } \\
\text { bus stop here? }\end{array}$ & $\begin{array}{l}\text { Humberto is working on the sentence } \\
\text { that this group is looking at and he is } \\
\text { using the correct word order in } \\
\text { German; however, he forgot the a- } \\
\text { Umlaut on halt }\end{array}$ \\
\hline $\begin{array}{l}5 \mathrm{C}: \text { No creo que er, no? } \\
\text { Porque esta hablando de } \\
\text { una cosa er, sie, es }\end{array}$ & $\begin{array}{l}\text { Idon't think it is he? } \\
\text { Because you were talking } \\
\text { about a thing he, she, it }\end{array}$ & $\begin{array}{l}\text { Claudia is questioning the third person } \\
\text { singular conjugation Humberto chose }\end{array}$ \\
\hline
\end{tabular}




\begin{tabular}{|c|c|c|}
\hline $6 \mathrm{H}:$ Creo & I belive so & Humberto insists \\
\hline $\begin{array}{l}7 \mathrm{C}: \text { er hält porque } \\
\text { recuerdate que suena } \\
\text { como ä }\end{array}$ & $\begin{array}{l}\text { he stops because } \\
\text { remember that it sounds } \\
\text { like } \ddot{a}\end{array}$ & $\begin{array}{l}\text { Claudia tells Humberto the correct } \\
\text { conjugation for this sentence with the } \\
\text { stem vowel change }\end{array}$ \\
\hline $\begin{array}{l}8 \mathrm{H} \text { : Entschuldigung wo } \\
\text { hält hier die Busse }\end{array}$ & $\begin{array}{l}\text { Excuse me where does } \\
\text { the busses stops here } \\
\text { [incorrect combination of } \\
\text { singular verb conjugation } \\
\text { with a plural noun] }\end{array}$ & $\begin{array}{l}\text { Now Humberto includes this } \\
\text { information into his sentence that he } \\
\text { transformed into plural; however, his } \\
\text { conjugation of 'to stop' is not correct, } \\
\text { because the a-Umlaut should not be } \\
\text { used in the plural }\end{array}$ \\
\hline 9 C: como a & $\begin{array}{l}\text { like a [pronounced like a } \\
\text { Spanish/German a] }\end{array}$ & $\begin{array}{l}\text { Claudia caught the mistake and tells } \\
\text { him that it should be with an "a", the } \\
\text { vowel sound "a" is identical between } \\
\text { Spanish and German so she is telling } \\
\text { him in Spanish what the correct vowel } \\
\text { sound would have been }\end{array}$ \\
\hline $\begin{array}{l}10 \mathrm{H} \text { : Entschuldigung wo } \\
\text { halt hier der Bus die } \\
\text { Busse, Entschuldigung } \\
\text { wo halt hier die Busse. } \\
\text { Enschuldigung wo halten } \\
\text { hier die Busse }\end{array}$ & $\begin{array}{l}\text { Excuse me where does } \\
\text { the bus the busses stop } \\
\text { here, Excuse me where do } \\
\text { the busses stop here. } \\
\text { Excuse me where stops } \\
\text { here the bus. }\end{array}$ & $\begin{array}{l}\text { Here Humberto uses the correct 'a' } \\
\text { sound that would apply to the plural } \\
\text { conjugation in both the singular and } \\
\text { the plural version of the sentence, } \\
\text { hereby overgeneralizing the feedback } \\
\text { he received }\end{array}$ \\
\hline $\begin{array}{l}11 \text { C: Meine Schwester } \\
\text { lässt den Hund ins Haus. } \\
\text { Meine Eltern ihr lässt den } \\
\text { Hund ins Haus. }\end{array}$ & $\begin{array}{l}\text { My sister lets the dog into } \\
\text { the house. My parents } \\
\text { you let the dog into the } \\
\text { house. }\end{array}$ & $\begin{array}{l}\text { Claudia moves on to the next sentence } \\
\text { and uses the correct conjugation for } \\
\text { singular, however not for the plural } \\
\text { version of the sentence }\end{array}$ \\
\hline $\begin{array}{l}12 \mathrm{H} \text { : Entschuldigung wo } \\
\text { hält hier der Bus. }\end{array}$ & $\begin{array}{l}\text { Excuse me where does } \\
\text { the bus stop here? }\end{array}$ & $\begin{array}{l}\text { Humberto corrects his sentence after } \\
\text { thinking about it and hearing } \\
\text { Claudia's example }\end{array}$ \\
\hline $13 \mathrm{C}:$ sig & It is your & $\begin{array}{l}\text { Claudia tells Humberto to continue } \\
\text { with a new sentence }\end{array}$ \\
\hline $\begin{array}{l}14 \mathrm{H} \text { : Ich schlafe jeden } \\
\text { Sonntagmorgen bis halb } \\
\text { zwölf. Ich }\end{array}$ & $\begin{array}{l}\text { I sleep every morning } \\
\text { until } 11: 30 . \text { I }\end{array}$ & $\begin{array}{l}\text { Humberto uses the correct conjugation } \\
\text { for the first person singular }\end{array}$ \\
\hline $15 \mathrm{C}$ : se ve como Dein & It looks like your & $\begin{array}{l}\text { Combination out of Spanish and } \\
\text { German }\end{array}$ \\
\hline $\begin{array}{l}\text { 16 H: Dein Freund } \\
\text { schlaft no }\end{array}$ & $\begin{array}{l}\text { Your friend sleeps, right? } \\
\text { (combination of German } \\
\text { and Spanish) }\end{array}$ & \\
\hline $17 \mathrm{C}: \mathrm{er}$ & he & \\
\hline $18 \mathrm{H}: \mathrm{ah}$ & $a h a$ & \\
\hline 19 C: so it will be schläft & Sleeps (third person) & $\begin{array}{l}\text { Claudia uses English here because A } \\
\text { is circulating around the room making } \\
\text { eye contact with C while listening to } \\
\text { this group [Claudia explained her } \\
\text { language choice here while reviewing } \\
\text { this transcript as part of her interview] }\end{array}$ \\
\hline $\begin{array}{l}20 \mathrm{H} \text { : schläft. Dein } \\
\text { Freund schläft jeden } \\
\text { Morgen bis halb zwölf. }\end{array}$ & $\begin{array}{l}\text { Sleeps. Your friend sleeps } \\
\text { every morning until } \\
\text { 11:30. }\end{array}$ & \\
\hline
\end{tabular}




\begin{tabular}{|c|c|c|}
\hline $\begin{array}{l}\text { 21C: ah schläfst du auch } \\
\text { am Wochenende so lang, } \\
\text { it would be if it is ihr it } \\
\text { doesn't have the Umlaut? }\end{array}$ & $\begin{array}{l}\text { Aha do you sleep so long } \\
\text { on the weekends, too. }\end{array}$ & $\begin{array}{l}\text { Claudia directly asks the teacher for } \\
\text { reassurance. In the question Claudia } \\
\text { asks about the second person plural } \\
\text { and that it doesn't have an Umlaut. }\end{array}$ \\
\hline 22 A: right & & $\begin{array}{l}\text { The instructor A is still listening to } \\
\text { this group and affirms C's statement }\end{array}$ \\
\hline $\begin{array}{l}23 \text { C: so here it would be } \\
\text { schlaft ihr, schläfst du } \\
\text { auch am Wochenende so } \\
\text { lang }\end{array}$ & $\begin{array}{l}\text { Do you all sleep, do you } \\
\text { also sleep long on the } \\
\text { weekend? }\end{array}$ & $\begin{array}{l}\text { Claudia is still using English in the } \\
\text { conversation with A, who is nodding } \\
\text { at her response. Claudia is correctly } \\
\text { using the singular and plural } \\
\text { conjugation }\end{array}$ \\
\hline $\begin{array}{l}24 \mathrm{H} \text { : Tante Bettina traegt } \\
\text { elegante Kleider }\end{array}$ & $\begin{array}{l}\text { Aunt Bettina wears } \\
\text { elegant clothing }\end{array}$ & \\
\hline $25 \mathrm{C}: \mathrm{du}$ & you & \\
\hline $\begin{array}{l}26 \mathrm{H}: \text { es lo mismo Tanta } \\
\text { Bettina porque du es lo } \\
\text { mismo du es traegst }\end{array}$ & $\begin{array}{l}\text { it is the same aunt Bettina } \\
\text { because you is the same } \\
\text { you wear }\end{array}$ & Combines Spanish with German \\
\hline $\begin{array}{l}27 \text { C: du se Tante Bettina } \\
\text { es sie }\end{array}$ & You aunt Bettina is she & $\begin{array}{l}\text { Spanish sentence structure is used } \\
\text { with German words incorporated } \\
\text { because the sentence is discussed }\end{array}$ \\
\hline $\begin{array}{l}28 \mathrm{H} \text { : oh entonces Tante } \\
\text { Bettina tragt elegante } \\
\text { Kleidung }\end{array}$ & $\begin{array}{l}\text { Oh so aunt Bettina wears } \\
\text { elegant clothing }\end{array}$ & \\
\hline \multicolumn{3}{|l|}{$29 \mathrm{C}:$ aha } \\
\hline $30 \mathrm{H}$ : Tante Bettina tragst & Aunt Bettina you wear & \\
\hline $\begin{array}{l}\text { 31 C: du Tante Bettina es } \\
\text { du }\end{array}$ & You aunt Bettina it is you & $\begin{array}{l}\text { Claudia is following a Spanish } \\
\text { sentence structure with "es" and uses } \\
\text { the German words from the example } \\
\text { to explain to Humberto that }\end{array}$ \\
\hline $\begin{array}{l}32 \mathrm{H} \text { : Tante Bettina du } \\
\text { tragst }\end{array}$ & Aunt Bettina you wear & \\
\hline $33 \mathrm{C}:$ No, estoy diciendo & No, I am saying & $\begin{array}{l}\text { Claudia is using Spanish when } \\
\text { explaining something to Humberto }\end{array}$ \\
\hline $\begin{array}{l}34 \mathrm{H}: \text { du tragst elegante } \\
\text { Kleidung. Tante Bettina } \\
\text { tragt elegante Kleidung } \\
\text { porque }\end{array}$ & $\begin{array}{l}\text { You wear elegant clothes. } \\
\text { Aunt Bettina wears } \\
\text { elegant clothes because }\end{array}$ & $\begin{array}{l}\text { The "porque" is added to the German } \\
\text { in Spanish indicating that he } \\
\text { understood what Claudia was trying to } \\
\text { explain to him earlier in Spanish }\end{array}$ \\
\hline $\begin{array}{l}35 \text { C: Robert trägt oft Uni } \\
\text { Sweatshirts. }\end{array}$ & $\begin{array}{l}\text { Robert often wears } \\
\text { university sweaters }\end{array}$ & $\begin{array}{l}\text { Claudia corrects the pronunciation of } \\
\text { trägt }\end{array}$ \\
\hline $\begin{array}{l}36 \text { H: Robert trägt oft Uni } \\
\text { Sweatshirts }\end{array}$ & $\begin{array}{l}\text { Robert often wears } \\
\text { university sweaters }\end{array}$ & $\begin{array}{l}\text { Humberto repeats after Claudia with } \\
\text { the correct pronunciation }\end{array}$ \\
\hline $\begin{array}{l}37 \mathrm{C}: \underline{\text { si es trägt pero es }} \\
\text { more traegt asi }\end{array}$ & $\frac{\text { Yes it is trägt but it is }}{\text { more like that traegt }}$ & $\begin{array}{l}\text { Claudia gives feedback in Spanish and } \\
\text { English on how to improve the a } \\
\text { umlaut pronunciation }\end{array}$ \\
\hline 38 H: Okay I get it. & & $\begin{array}{l}\text { Humberto got the concept and } \\
\text { acknowledges that he understood it in } \\
\text { English }\end{array}$ \\
\hline
\end{tabular}

Line 37 in this example shows a language combination out of Spanish German and English applied in one statement while Claudia is explaining to 
Humberto how to pronounce the third person singular conjugation of "tragen" which is "trägt". Because Claudia has used one English word to address Humberto he replies in English in line 38 which is a deviation to the rest of their conversation that is carried out in Spanish and German. Garcia (2009) explains that multilinguals use one linguistic repertoire for their communicative needs, and this is what can be observed in the conversation between Claudia and Humberto. They both know Spanish and English and are learning German. While they are practicing forming German sentences they discuss the correct use of the conjugations in Spanish. The spontaneous language use in this group above shows that the two students are drawing on their full linguistic repertoire to make sense of the task at hand. Claudia draws connections between cultural identity and language use during her interview:

"On my Kindergarten here, my mom wanted me to speak English so she put me in a really weird school that they only spoke English and they were like a Lutheran school cause there were only white people there were no Latinos or anything" (Interview 03/19/2018).

Due to the fact, that Claudia was placed in an educational setting of Englishonly speaker she was exposed to English early. Her comment here reveals that she connects "white people" with being monolingual English speakers. Claudia describes her language use with friends in the following way:

"With my childhood friends I always speak Spanish most of them they don't speak one word in English they don't even know how to speak English which is weird because they live on the border, so I think it is kind of weird" (Interview 03/19/2018).

Living as a transfronteriza, a person who crosses the border frequently allows Claudia to understand the mentalities of people on both sides of the border (Esquinca, 2013). She speaks both Spanish and English and expresses a disbelief that her childhood friends are not bilingual like herself.

Excerpt 2 is from the German 2 class where I go through a list of vocabulary and ask the students to go over the list with a partner to find the plural of the nouns that are shown in singular. Lino and Carlos frequently work together and translanguage to make sense out of German vocabulary.
A: Annabell (instructor)
C: Carlos
L: Lino
Spanish is underlined in the original utterance and the English translation 
Table 2. Excerpt 2 In-class Conversation

\begin{tabular}{|c|c|c|}
\hline Utterance & $\begin{array}{c}\text { English } \\
\text { translation }\end{array}$ & Explanation \\
\hline $\begin{array}{l}\text { 1 A: die Kaufhäuser okay so the au with } \\
\text { the Umlaut is almost gonna be the oy as } \\
\text { in boy, die Kaufhäuser, der Verkäufer, } \\
\text { die Verkäuferin, and then die } \\
\text { Verkäuferinnen so those are the ones } \\
\text { that we will be focusing on, so go ahead } \\
\text { and go over the list with someone ask } \\
\text { how would you say the plural and how } \\
\text { would you say it. For that side we will } \\
\text { do a minute and then we will switch }\end{array}$ & $\begin{array}{l}\text { the sales person } \\
\text { (male and } \\
\text { female) }\end{array}$ & $\begin{array}{l}\text { Teacher is showing } \\
\text { students a list of German } \\
\text { vocabulary and gives } \\
\text { directions }\end{array}$ \\
\hline 2 L: Qué tenemos que hacer? & $\begin{array}{l}\text { What are we } \\
\text { supposed to do? }\end{array}$ & $\begin{array}{l}\text { Lino and Carlos usually } \\
\text { work together and talk in } \\
\text { Spanish to each other here } \\
\text { Lino asks Carlos }\end{array}$ \\
\hline $\begin{array}{l}3 \mathrm{C}: \text { Tenemos que leer el lado izquierdo } \\
\text { y derecho }\end{array}$ & $\begin{array}{l}\frac{\text { We are supposed }}{\text { Read the left and }} \\
\text { right side }\end{array}$ & $\begin{array}{l}\text { Carlos answers and gives a } \\
\text { translation of the directions } \\
\text { that were given in English }\end{array}$ \\
\hline 4 L: Entonces & Ok then & \\
\hline 5 C: Frauen, Fraunen o Frauen? & $\begin{array}{l}\text { Women or } \\
\text { women }\end{array}$ & $\begin{array}{l}\text { Carlos is unsure how to } \\
\text { pronounce women in } \\
\text { German so he is asking } \\
\text { Lino. }\end{array}$ \\
\hline 6 L: Frauen & women & $\begin{array}{l}\text { Lino gives the correct } \\
\text { pronunciation }\end{array}$ \\
\hline $\begin{array}{l}7 \text { C: Frauen, das Kleidergeschäft } \\
\text { (Gliedergeschäft), die Klamotten [Lino } \\
\text { is also reading it] }\end{array}$ & $\begin{array}{l}\text { Women, the } \\
\text { clothing store, } \\
\text { the clothes }\end{array}$ & $\begin{array}{l}\text { Carlos is reading the } \mathrm{K} \text { as } \mathrm{G} \\
\text { in department store which } \\
\text { is common in some } \\
\text { German dialects }\end{array}$ \\
\hline $\begin{array}{l}8 \mathrm{~L} \text { : die Klamotten. Estamos viendo } \\
\text { cómo se escribe en plural y en normales }\end{array}$ & $\begin{array}{l}\text { The clothes. We } \\
\text { are seeing how it } \\
\text { is written in } \\
\text { plural and in } \\
\text { normal }\end{array}$ & \\
\hline 9 C: Y luego & And then & \\
\hline $\begin{array}{l}10 \text { A: Verkäufer is male, Verkäuferin is } \\
\text { female }\end{array}$ & $\begin{array}{l}\text { Sales person is } \\
\text { male, sales lady } \\
\text { is female }\end{array}$ & $\begin{array}{l}\text { The instructor gives the } \\
\text { singular for sales person } \\
\text { masculine and feminine }\end{array}$ \\
\hline $11 \mathrm{C}:$ ah era feminino & $\frac{\text { Aha it was }}{\text { feminine }}$ & $\begin{array}{l}\text { Carlos affirms that he } \\
\text { understood what was being } \\
\text { said in English with his } \\
\text { utterance in Spanish that is } \\
\text { a form of inner speech that } \\
\text { he happened to say out loud } \\
\text { to himself }\end{array}$ \\
\hline 12 A: die Verkäuferinnen & The sales ladies & \\
\hline 13 C: Oh sí era plural & $\begin{array}{l}\text { Oh yes it was } \\
\text { plural }\end{array}$ & $\begin{array}{l}\text { Carlos demonstrates } \\
\text { understanding of what }\end{array}$ \\
\hline
\end{tabular}




\begin{tabular}{|c|c|c|}
\hline & & $\begin{array}{l}\text { instructor said in this } \\
\text { utterance in this form of } \\
\text { inner speech }\end{array}$ \\
\hline $\begin{array}{l}14 \text { A: Okay, I'll let you work on these } \\
\text { words so ask each other for the } \\
\text { combinations }\end{array}$ & & $\begin{array}{l}\text { Teacher provides more } \\
\text { directions in English }\end{array}$ \\
\hline $\begin{array}{l}15 \mathrm{C}: \text { Tenemos que traducirlos unos, } \\
\text { no? }\end{array}$ & $\begin{array}{l}\text { We have to } \\
\text { translate some, } \\
\text { no? }\end{array}$ & $\begin{array}{l}\text { Carlos now asks a } \\
\text { rhetorical question }\end{array}$ \\
\hline 16 L: Qué, qué? & what, what? & $\begin{array}{l}\text { Lino did not understand the } \\
\text { directions given in English }\end{array}$ \\
\hline $\begin{array}{l}17 \mathrm{C}: \underline{\text { Tenemos que traducirlos, haz de }} \\
\text { cuenta, yo te pregunto ah cómo se dice } \\
\text { "loud" }\end{array}$ & $\begin{array}{l}\frac{\text { we have to }}{\text { translate, do not }} \\
\frac{\text { tell me I ask you }}{\text { how do you say }} \\
\text { loud }\end{array}$ & $\begin{array}{l}\text { But Carlos did understand } \\
\text { the directions and now } \\
\text { translates the original } \\
\text { directions to Lino. Carlos is } \\
\text { using Spanish but is using } \\
\text { the English loud to elicit the } \\
\text { German translation }\end{array}$ \\
\hline $18 \mathrm{~L}:$ loud & & $\begin{array}{l}\text { Lino repeats loud in } \\
\text { English }\end{array}$ \\
\hline $\begin{array}{l}19 \text { C: pero te pregunte en inglés y tú me } \\
\text { respondes en alemán }\end{array}$ & $\begin{array}{l}\frac{\text { But I ask you in }}{\text { English and you }} \\
\text { answer me in } \\
\text { German }\end{array}$ & $\begin{array}{l}\text { Carlos explains in Spanish } \\
\text { that he is looking for the } \\
\text { German }\end{array}$ \\
\hline $20 \mathrm{~L}:$ Ah, laut & $\overline{\text { Aha loud }}$ & $\begin{array}{l}\text { Lino understands what he is } \\
\text { supposed to do and gives } \\
\text { the German translation }\end{array}$ \\
\hline $21 \mathrm{C}: \underline{\mathrm{Y} \text { tú me preguntes a mi }}$ & And you ask me & $\begin{array}{l}\text { Carlos continues to give } \\
\text { directions in Spanish }\end{array}$ \\
\hline $\begin{array}{l}22 \mathrm{C} \text { : to take nehmen miralo yo pensé } \\
\text { que esa etaba mas relacionada con } \\
\text { nombre }\end{array}$ & $\begin{array}{l}\text { To take look at } \\
\text { that I thought } \\
\text { that nehmen was } \\
\text { more related to } \\
\text { name }\end{array}$ & $\begin{array}{l}\text { The group discussed that it } \\
\text { could be related to the word } \\
\text { "name" in English which is } \\
\text { also written as "Name" in } \\
\text { German. }\end{array}$ \\
\hline 23 L: Yo también & Me too & \\
\hline $\begin{array}{l}24 \mathrm{C}: \underline{\text { Porque esta tiene } \mathrm{h} \text { es por eso }} \\
\text { porque se viene de nehmen creo ich } \\
\text { nehme }\end{array}$ & $\begin{array}{l}\text { Because this one } \\
\text { has an h that is } \\
\text { why it comes } \\
\text { from to take I } \\
\text { think I take }\end{array}$ & $\begin{array}{l}\text { Carlos demonstrates } \\
\text { metalinguistic awareness in } \\
\text { this multilingual vocabulary } \\
\text { inquiry. }\end{array}$ \\
\hline $25 \mathrm{~L}$ : la que hicimos el nehmen $\underline{\text { con } \mathrm{h}}$ & $\frac{\text { What we did to }}{\text { take with } h}$ & \\
\hline \multicolumn{3}{|l|}{$26 \mathrm{C}: \mathrm{ah}$} \\
\hline $27 \mathrm{~L}:$ sehen & To see & \\
\hline \multicolumn{3}{|l|}{$28 \mathrm{C}$ : to become } \\
\hline \multicolumn{3}{|l|}{ 29 L: hmm? } \\
\hline \multicolumn{3}{|l|}{$30 \mathrm{C}$ : to become } \\
\hline 31 L: werden (rolling r) & To become & \\
\hline $32 \mathrm{C}$ : werden creo que ja & $\begin{array}{l}\text { To become I } \\
\text { believe that yes }\end{array}$ & $\begin{array}{l}\text { German and Spanish are } \\
\text { both used in this utterance }\end{array}$ \\
\hline
\end{tabular}




\begin{tabular}{|c|c|c|}
\hline & & ja is German for yes \\
\hline 33 L: Entonces qué hacemos? & $\begin{array}{l}\text { Then what do we } \\
\text { do? }\end{array}$ & $\begin{array}{l}\text { Lino is asking for } \\
\text { clarification on the task in } \\
\text { Spanish }\end{array}$ \\
\hline $34 \mathrm{C}$ : Lo mismo, to bake & The same, to & \\
\hline 35 L: backen, er bäckt & $\begin{array}{l}\text { To bake, he } \\
\text { bakes }\end{array}$ & \\
\hline $36 \mathrm{C}$ : $\underline{\text { Bueno }}$ to drive & $\underline{\text { Good }}$ & $\begin{array}{l}\text { The feedback is provided in } \\
\text { Spanish then in English, } \\
\text { Carlos is asking for "to } \\
\text { drive" }\end{array}$ \\
\hline 37 L: qué? & what & \\
\hline $38 \mathrm{C}:$ conducir & To drive & $\begin{array}{l}\text { They had agreed to ask } \\
\text { each other in English for } \\
\text { the German translation and } \\
\text { are using Spanish here } \\
\text { because Lino did not } \\
\text { understand when asked in } \\
\text { English }\end{array}$ \\
\hline 39 L: to drive er fährt, to eat & He drives & $\begin{array}{l}\text { Lino can give the answer in } \\
\text { German }\end{array}$ \\
\hline $40 \mathrm{C}$ : to eat era essen & To eat was to eat & \\
\hline 41 L: essen, er isst & To eat, he eats & \\
\hline $\begin{array}{l}42 \mathrm{C} \text { : zahlen bezahlen no se es esta } \\
\text { curiosa aver to run }\end{array}$ & $\begin{array}{l}\text { To pay I don't } \\
\text { know it is } \\
\text { curious let's see }\end{array}$ & \\
\hline \multicolumn{3}{|l|}{$43 \mathrm{~L}$ : to run laufen } \\
\hline $\begin{array}{l}44 \mathrm{C} \text { : Yo pensaba que era como que } \\
\text { laugh para la risa no es to wash }\end{array}$ & $\begin{array}{l}\frac{\text { I thought it was }}{\text { like for laugh it }} \\
\underline{\text { is not }}\end{array}$ & $\begin{array}{l}\text { Making associations } \\
\text { between German words } \\
\text { when trying to understand } \\
\text { their meaning }\end{array}$ \\
\hline $\begin{array}{l}45 \mathrm{~L}: \text { waschen, er wäscht, to bake no ya } \\
\text { te la marque to get }\end{array}$ & $\begin{array}{l}\text { To wash, he } \\
\text { washes, to bake, } \\
\text { Ialready } \\
\text { marked it, to get }\end{array}$ & \\
\hline \multicolumn{3}{|l|}{$46 \mathrm{C}$ : to get bekommen } \\
\hline $47 \mathrm{~L}: \mathrm{mmh}$ donde esta? & Where is it? & \\
\hline $48 \mathrm{C}:$ to need hasta arriba bueno & At the top good & \\
\hline \multicolumn{3}{|l|}{$49 \mathrm{~L}$ : brauchen, to read } \\
\hline $\begin{array}{l}50 \mathrm{C}: \text { leer, ah ya le vi, lesen er liest aver } \\
\text { to sleep }\end{array}$ & $\begin{array}{l}\text { To read I saw it, } \\
\text { to read he reads } \\
\text { let's see to sleep }\end{array}$ & $\begin{array}{l}\text { Spanish translation from } \\
\text { English is given before the } \\
\text { German translation }\end{array}$ \\
\hline \multicolumn{3}{|l|}{ 51 L: sleep? } \\
\hline $\begin{array}{l}52 \mathrm{C} \text { : schlafen y no se decirlo to sleep } \\
\text { pero Plautdietsch }\end{array}$ & $\begin{array}{l}\text { To sleep and } \\
\text { they don't say to } \\
\text { sleep in low } \\
\text { German }\end{array}$ & $\begin{array}{l}\text { Carlos is familiar with } \\
\text { Plautdietsch a German } \\
\text { dialect that is spoken by the } \\
\text { Mennonites a religious } \\
\text { community living in } \\
\text { Chihuahua, Mexico }\end{array}$ \\
\hline
\end{tabular}




\begin{tabular}{|c|c|c|}
\hline 53 L: Plautdietsch cual es ese? & $\begin{array}{l}\text { Low German } \\
\text { which one is } \\
\text { that? }\end{array}$ & \\
\hline $54 \mathrm{C}$ : El aleman bajo de los Menonitas & $\begin{array}{l}\text { The low German } \\
\text { of the } \\
\text { Mennonites }\end{array}$ & \\
\hline \multicolumn{3}{|l|}{$55 \mathrm{~L}:$ aha } \\
\hline $\begin{array}{l}56 \mathrm{C}: \underline{\text { Se diece }} \text { mischläft se dice que } \\
\text { tiene sueno }\end{array}$ & $\begin{array}{l}\text { They say ... when } \\
\text { one is tired }\end{array}$ & $\begin{array}{l}\text { Carlos is sharing his } \\
\text { knowledge of Plattdeutsch } \\
\text { with Lino }\end{array}$ \\
\hline $\begin{array}{l}57 \mathrm{~L}: \text { pero de dónde aprendiste eso? } \\
\text { C: } \underline{\text { de Monika }} \\
\text { L: } \underline{\text { si se cierto }}\end{array}$ & $\begin{array}{l}\text { But where did } \\
\text { you learn that } \\
\text { From Monika } \\
\text { Yes that is true }\end{array}$ & $\begin{array}{l}\text { Lino is wondering why } \\
\text { Carlos knows it in } \\
\text { Plautdietsch and he reminds } \\
\text { him because of Monika, his } \\
\text { girlfriend who grew up in } \\
\text { the Mennonite community } \\
\text { speaking the German } \\
\text { dialect, Spanish and } \\
\text { English }\end{array}$ \\
\hline
\end{tabular}

Lino and Carlos are translanguaging for meaning making and show that they comprehend what is being said in English and German by the teacher by making their connections to the German vocabulary in Spanish for example in utterance number 11 and 13. In line 16 Lino is expressing confusion about the directions that were given in English but because the two students were grouped according to their home language which is Spanish Carlos was able to quickly clarify the directions and the of them were able to complete the task at hand Starting with utterance 22 Carlos and Lino are discussing that to them that the German verb "nehmen" has resemblance to "Name" phonetically when pronounced in English the word name sounds similar to "nehmen" when pronounced in German this multilingual vocabulary inquiry shows that the two students are drawing on their full linguistic repertoire (Garcia \&Wei, 2014). During their interviews the participants stated that they used both English and Spanish to make sense of German.

Starting with line 51 until the end of Excerpt 2 a discussion around Plautdietsch unfolds because after being asked for the translation of the verb to sleep Carlos draws a connection to this low German dialect that he also happens to be familiar with. This Excerpt 2 shows that students who are given the possibility to use their full linguistic repertoire will be able to draw on knowledge that is tied to their cultural identities and that of their respective communities. Being able to make these connections enriches the German language learning experience, because students can make meaning of the new language by building on existing background knowledge (Garcia \& Wei, 2014). Claudia, Humberto, Carlos and Lino made connections between cultural identity and language choices.

Students identifying as Mexican-Americans in this study are showing a different language use pattern compared with those who self-identify as Mexicans. Below is an example of two students who self-identify as Mexican-American and have knowledge of both English and Spanish but prefer to use English in the 
classroom. This activity took place after spring break and students were asking each other how they had spent spring break. Iskra and Jay are holding their conversation in German and use English to ask questions and explain what is being said, as well as to translate back into German.

Iskra $=\mathrm{I}$

Jay $=$ J

Table 3. Excerpt 3 in-class Conversation

\begin{tabular}{|l|l|l|}
\hline \multicolumn{1}{|c|}{ Utterance } & \multicolumn{1}{|c|}{ English Translation } & \multicolumn{1}{c|}{ Explanation } \\
\hline $\begin{array}{l}\text { I: Wo warst du in den } \\
\text { Frühlingsferien? }\end{array}$ & $\begin{array}{l}\text { Where were you during } \\
\text { sprink break? }\end{array}$ & \\
\hline J: Ich war in Las Vegas. & I was in Las Vegas. & \\
\hline I: Kennst du oh you ask me & Do you know... & $\begin{array}{l}\text { Explanation of the task is } \\
\text { given in English }\end{array}$ \\
\hline J: Kennst du Las Vegas? & Do you know Las Vegas? & \\
\hline I: Ja ich kenne Las Vegas. & Yes I know Las Vegas. & \\
\hline $\begin{array}{l}\text { J: Ah, warst du schon in Las } \\
\text { Vegas? [Pause 2 seconds] }\end{array}$ & $\begin{array}{l}\text { Have you been to Las } \\
\text { Vegas? }\end{array}$ & \\
\hline I: What's that? & & $\begin{array}{l}\text { Question about meaning is } \\
\text { asked and answered in } \\
\text { English }\end{array}$ \\
\hline $\begin{array}{l}\text { J: Have you been in Las } \\
\text { Vegas before have you been } \\
\text { to... }\end{array}$ & & $\begin{array}{l}\text { J is trying to explain to I } \\
\text { what he has just asked her } \\
\text { in German }\end{array}$ \\
\hline I: Ah & & $\begin{array}{l}\text { Iskra did not understand the } \\
\text { question in German and is } \\
\text { looking for the question in } \\
\text { the textbook }\end{array}$ \\
& & $\begin{array}{l}\text { J assists in pointing out } \\
\text { where to look for the } \\
\text { sentence structure }\end{array}$ \\
\hline J: It's over there. & & \\
\hline I: Ja, ich war in Las Vegas. & Yes I was in Las Vegas. & \\
\hline J: Gefällt dir Las Vegas? & Do you like it? & $\begin{array}{l}\text { The directions were to get a } \\
\text { conversation going so J tells } \\
\text { I to ask a question }\end{array}$ \\
\hline I: Ja, Las Vegas gefällt mir. & Yes, I like Las Vegas. & \\
\hline $\begin{array}{l}\text { J: Those are the questions. } \\
\text { So I'll ask you okay? Wo } \\
\text { warst du in den } \\
\text { Frühlingsferien? }\end{array}$ & $\begin{array}{l}\text { Where have you been } \\
\text { during spring break? }\end{array}$ & \\
\hline I: Ich war in ah Cancun. & I was in uh Cancun. & \\
\hline $\begin{array}{l}\text { J: You say: Kennst du } \\
\text { Cancun? }\end{array}$ & Do you know & \\
\hline I: Kennst du Cancun? & Do you know ... & \\
\hline $\begin{array}{l}\text { J: Ahm nein ich kenne } \\
\text { Cancun nicht. }\end{array}$ & No I don't know ... & \\
\hline & & \\
\hline
\end{tabular}

On the topic of classroom atmosphere Claudia states: 
"I find every activity helpful cause it's very interactive not just sitting there and listening to someone talk and I don't know I like the way the class goes. And I think that is why people actually go even when you don't take attendance and stuff like that normally classes get emptier and emptier cause people don't go but German class is always full, I think it's because people like it. I'm always excited to go because I think I'm actually going to learn something" (Interview 03/19/2018)

Jay commented the following on the classroom environment: "over here it is always relaxed, and I always have fun" (Interview 03/19//2018)

The interviews reveal that the participants reflect positively on the set-up of the class which they describe as comfortable and conducive to learning. One element that participants mentioned was the positive effect of collaborative group work for their learning. Jay is a student who spoke Spanish and English languages did not identify as bilingual because he is applying a different standard to himself.

"I would say I know one language so I'm not bilingual but I know a lot of Spanish but not enough to be bilingual" (Interview 03/19/2018).

This understanding of biliteracy reflects a monolingual view on languages Jay judges his abilities in Spanish according to an internalized deficit discourse. According to this standard his Spanish does not measure up with his English.

At the same time Jay states the following when asked how he makes sense out of new German vocabulary:

"I usually use English but if I am trying to figure out a word that is when I go to Spanish or I know how to say the letters instead of English with the ch and the sh I go to Spanish and it makes it a lot easier to think "(Interview 03/19/2018).

Although he is able to use Spanish to make sense out of German he does not self-identify as bilingual. Jay's mother is Mexican and his father American he selfidentified in the following way: "I'm American but I'm of Hispanic descendance" (Interview 03/19/2018).

Jay identifies as American now connections can be made between discourses of Americans being English only speakers and his own self-image as a monolingual American (Hornberger, 2002). Claudia talked about Mexican-Americans who do not use their Spanish language skills:

"because for here speaking Spanish makes you, I don't know people see it as it is better to pretend you don't speak Spanish it's like a bad thing I don't know why so maybe they are always trying to not speaking it but I mean it is their first language and at home they speak it and sometimes it is so weird because I see parents speak in Spanish to their kids and kids answering in English and I don't get it maybe it is the way I was raised because I always see it as instead of wanting more you want less" (Interview 03/20/2018). 
In this comment on Spanish the passing for white theme emerges particularly since speaking Spanish is often associated with an immigrant community and it is a marker of non-whiteness. Nativist discourses are present in the border and are noticed by the participants. "The power I have seen: white people that are like 'why are you speaking Spanish here? Speak American here."' (Interview 03/22/2018)

Within the group of participants, it can be noticed that language shift, as well as language loss have been going on. The group of students who are German heritage language learners have all been experiencing language shift first hand. They described that their German-speaking mothers would switch to speaking in English once they moved from Germany to the United States. Consequently, English became the language that was dominantly spoken at the expense of German. Language shift and loss can also be observed within the MexicanAmerican and Latina/o participants. As English became the more dominant language in their families over time, particularly, with a bilingual educational system that transitions students towards speaking English as their dominant language. Within the group of heritage language learners of German only one person used German consistently together with English at home. The other heritage language learners would hear it only in conversations with grandparents but would rely on translations to English.

Table 4. Excerpt 4 In-class Conversation

\begin{tabular}{|l|l|}
\hline Utterance & \multicolumn{1}{|c|}{ Explanation } \\
\hline $\begin{array}{l}\text { Adrian: So I guess we can use this time to talk } \\
\text { about how German relates to other languages I } \\
\text { guess. Cuz the sentence structure is very } \\
\text { similar to Spanish. }\end{array}$ & $\begin{array}{l}\text { This group had completed their task } \\
\text { ahead of all the other groups so Adrian } \\
\text { has the idea for this metalinguistic } \\
\text { conversation }\end{array}$ \\
\hline Stephanie: Yes. & $\begin{array}{l}\text { Self-identifies as Mexican-American } \\
\text { based on her interviews }\end{array}$ \\
\hline Jarid: I don't speak Spanish so I don't know. & $\begin{array}{l}\text { Jarid was born in Germany and has been } \\
\text { speaking English all his life }\end{array}$ \\
\hline $\begin{array}{l}\text { Jonathan: I told you my background in } \\
\text { Spanish. }\end{array}$ & $\begin{array}{l}\text { Although of Spanish-speaking decent } \\
\text { Jonathan does not speak Spanish }\end{array}$ \\
\hline $\begin{array}{l}\text { Adrian: Wait, I know Spanish and you don't } \\
\text { get along together. }\end{array}$ & \\
\hline Jonathan: Haha (laughing) & $\begin{array}{l}\text { Adrian: It was my first language, I learned } \\
\text { Spanish and then I learned German at the same } \\
\text { time ... }\end{array}$ \\
\hline $\begin{array}{l}\text { Jarid: Oh, that is awesome. } \\
\text { Adrian: Yeah }\end{array}$ & $\begin{array}{l}\text { where he was able to take German every } \\
\text { year }\end{array}$ \\
\hline $\begin{array}{l}\text { Stephanie: I speak Spanish and English } \\
\text { (laughing) }\end{array}$ & \\
\hline $\begin{array}{l}\text { Jonathan: Like me. The most I notice Spanish } \\
\text { is when my grandmother is cussing me out and } \\
\text { that is at on a daily basis. } \\
\text { Group is laughing }\end{array}$ & $\begin{array}{l}\text { The grandmother is Spanish-speaking } \\
\text { while Jonathan will respond to her in } \\
\text { English as he explained during his } \\
\text { interview }\end{array}$ \\
\hline
\end{tabular}


Table 5. Excerpt 5 In-class conversation

\begin{tabular}{|c|c|c|}
\hline Utterance & English translation & Explanation \\
\hline $\begin{array}{llll}\text { Shawn: } & \text { Regnet } & \text { es } & \text { am } \\
\text { Südpol? } & & & \\
\end{array}$ & $\begin{array}{l}\text { Does it rain at the south } \\
\text { pole? }\end{array}$ & \\
\hline $\begin{array}{l}\text { Andre: Nein, am Südpol } \\
\text { regnet es nicht. }\end{array}$ & $\begin{array}{l}\text { No, at the south pole it } \\
\text { does not rain. }\end{array}$ & \\
\hline $\begin{array}{l}\text { Shawn: Mmh (noding) } \\
\text { Andre: Schneit es oft in } \\
\text { Houston? }\end{array}$ & Does it snow in Houston? & $\begin{array}{l}\text { Shawn is approving } \\
\text { sentence Andre just told him }\end{array}$ \\
\hline $\begin{array}{l}\text { Alex: Nein, scheint es nicht } \\
\text { oft in Houston. }\end{array}$ & $\begin{array}{l}\text { No, it does not shine often } \\
\text { in Houston. }\end{array}$ & $\begin{array}{l}\text { Schneit and scheint are often } \\
\text { confused by German learners }\end{array}$ \\
\hline Shawn: schneit & snow & $\begin{array}{l}\text { Shawn did notice the } \\
\text { mistake and is correcting } \\
\text { Alex }\end{array}$ \\
\hline Alex: Nein, es schneit & No, it snows & $\begin{array}{l}\text { Alex is using the correct } \\
\text { verb but hesitates } \\
\text { completing the sentence }\end{array}$ \\
\hline Shawn: nicht oft & Not often & Shawn is helping him \\
\hline $\begin{array}{l}\text { Alex: nicht oft in Houston. } \\
\text { Regnet es in Israel viel? }\end{array}$ & $\begin{array}{l}\text { Not often in Houston. } \\
\text { Does it rain much in } \\
\text { Israel? }\end{array}$ & $\begin{array}{l}\text { Alex is completing the } \\
\text { sentence with the help } \\
\text { provided }\end{array}$ \\
\hline Andre: Nein, ir & No, in Israel & $\begin{array}{l}\text { Andre gets stuck with his } \\
\text { sentence }\end{array}$ \\
\hline Shawn: ... regnet es nicht viel & It doe & $\begin{array}{l}\text { Shawn is helping to } \\
\text { complete the sentence the } \\
\text { focus of the activity was on } \\
\text { the negation }\end{array}$ \\
\hline Andre: nicht viel & Not much & $\begin{array}{l}\text { Andre is repeating the } \\
\text { negation part but without the } \\
\text { verb }\end{array}$ \\
\hline $\begin{array}{l}\text { Shawn: I think it is regnet es } \\
\text { nicht viel }\end{array}$ & $\begin{array}{l}\text { I think it is does it not rain } \\
\text { much. }\end{array}$ & Shawn provides feedback \\
\hline $\begin{array}{l}\text { Andre: In Israel regnet es } \\
\text { nicht viel. }\end{array}$ & $\begin{array}{l}\text { In Israel it does not rain } \\
\text { much. }\end{array}$ & $\begin{array}{l}\text { Andre repeats what Shawn } \\
\text { had told him }\end{array}$ \\
\hline $\begin{array}{l}\text { Shawn: Ist der Winter in } \\
\text { Italien sehr kalt? }\end{array}$ & $\begin{array}{l}\text { Is the winter in Italy very } \\
\text { cold? }\end{array}$ & \\
\hline Andre: nicht Winter ist kalt & Not winter is very cold & $\begin{array}{l}\text { Andre answers with this } \\
\text { sentence fragment }\end{array}$ \\
\hline $\begin{array}{l}\text { Shawn: Nein, in Italien der } \\
\text { Winter ist nicht sehr kalt. }\end{array}$ & $\begin{array}{l}\text { No, in Italy the winter is } \\
\text { not very cold. }\end{array}$ & $\begin{array}{l}\text { Shawn gives the complete } \\
\text { negation as a sentence }\end{array}$ \\
\hline $\begin{array}{l}\text { Andre: Nein, in Italien der } \\
\text { Winter ist sehr kalt, ist nicht } \\
\text { sehr kalt. Beginnt der } \\
\text { Sommer im Julei Juli? }\end{array}$ & $\begin{array}{l}\text { No, in Italy the winter is } \\
\text { very cold, not very cold. } \\
\text { Does the summer begin in } \\
\text { July? }\end{array}$ & $\begin{array}{l}\text { Andre repeats the sentence, } \\
\text { he has trouble pronouncing } \\
\text { Juli }\end{array}$ \\
\hline $\begin{array}{l}\text { Alex: Nein, der Sommer } \\
\text { beginnt nicht im Julei. }\end{array}$ & $\begin{array}{l}\text { No, the summer does not } \\
\text { begin in July. }\end{array}$ & \\
\hline Andre: Is it Julei or Juli? & & $\begin{array}{l}\text { Andre is confused as to how } \\
\text { to pronounce Juli }\end{array}$ \\
\hline Shawn: Juli & & correctly pronounced \\
\hline
\end{tabular}


Students like Iskra and Jay described that they feel more comfortable with using English since that is what they have been socialized into throughout their academic careers. Although Spanish might be heard at home these students did not consider Spanish to be an academic language that they felt comfortable using in an academic setting.

The following example is from a group in the German 1 class that consists of students who partly identify as Americans and as Mexican-Americans. This metalinguistic discussion is an example of how students describe themselves based on their language use. During the interviews that were conducted as part of this study all participants had the chance to self-identify and make connections to their identity based on the command of languages they have. Jarid, although born in Germany, identifies as American because he "only speaks American" which hints at a nativist discourse of associating American with the knowledge of Englishonly, while others hyphenated their identities based on the language they speak. Stephanie in the excerpt below talks about speaking Spanish and English. In her saying she speaks Spanish and English she shows consistency also during her interview she identifies as Mexican-American and bilingual. Jonathan and Adrian both identify as American with Spanish "descendants" a term they used during their interviews.

Students identifying as American were using English for their communicative needs in the German class. In the example below Shawn could be classified as a heritage German learner. His group relies on his knowledge and trusts his feedback although he did not have formal instruction in German he has been exposed to it through his German grandparents and his German mother. $\mathrm{He}$ is a resource for his group because he is able to help them to identify mistakes in their German phrases. Moreover, Shawn can give feedback to the group members that they are able to incorporate while practicing their sentences.

The excerpt below is an example of a group conversation with another German heritage language learner Evan. In Excerpt 5 Shawn is a German heritage learner who is a resource to his group and offers feedback to his group members. In Excerpt 6 Evan identifies as English only speaker although his father is Mexican and his mother has German ancestry; however, Evan speaks only English because as he describes: "I would usually kind of ignore Spanish just because I was arrogant ... I only knew English so I was like: ah whatever." Evan made this reflection about previous opinions he had about Spanish indicating that there might have been a change. The conversation below is an example of the group practicing how to tell time in German, and Evan translanguages between German and English when it is his time to speak. The activity involved reading time in German; different clocks were shown and students had to ask each other for the time and read the clocks in German. Time is told differently in German compared to English and his group is explaining that to Evan by modeling it. Nico and Victor are two bilingual speakers who are very comfortable speaking in Spanish to each other. Mario is more comfortable speaking English but has knowledge of both Spanish and English; the common language that is used to explanations here is English. Evan's opinions about not wanting to speak Spanish have lead him to lose the Spanish he knew as a young child. He always ignored Spanish because it was 
not interesting to him as he explained during his series of interviews his preference for English determined the language of choice for this group of students who might chose to work in Spanish if he was not present. Complex identities around languages are common in the German classes at this border university because the class becomes a space to reflect on other languages one might know or used to know and it draws attentions to discourses and believes and ideologies about languages and the value of language. Evan explained that although Spanish was heard frequently either on his Dad's side of the family or in the community, he did not feel the importance of knowing Spanish as a consequence he cannot communicate well with his grandmother.
E: Evan
M: Mario
V: Victor
$\mathrm{N}$ : Nico

Table 6. Excerpt 6 In-class Conversation

\begin{tabular}{|c|c|c|}
\hline Utterance & English Translation & Explanation \\
\hline $\begin{array}{l}\text { E: So, I don't understand } \\
\text { it }\end{array}$ & & $\begin{array}{l}\text { Evan is confused with the way time } \\
\text { is told in German }\end{array}$ \\
\hline M: You just read it. & & Mario is trying to give him a hint \\
\hline \multicolumn{3}{|l|}{ E: Okay so } \\
\hline $\begin{array}{l}\text { M: it is six fifty five } \\
\text { instead of five minutes to }\end{array}$ & & $\begin{array}{l}\text { Mario continues to explain more of } \\
\text { how time is read }\end{array}$ \\
\hline $\begin{array}{l}\text { E: Okay. Wie viel Uhr ist } \\
\text { es? }\end{array}$ & What time is it? & \\
\hline $\begin{array}{l}\text { V: Es ist zwanzig Uhr } \\
\text { fünf }\end{array}$ & $\begin{array}{l}\text { It is } 20 \text { minutes until } \\
5\end{array}$ & \\
\hline $\begin{array}{l}\text { E: Es ist sechs fifty five } \\
\text { Uhr }\end{array}$ & $\begin{array}{l}\text { It is six fifty five } \\
\text { o'clock }\end{array}$ & $\begin{array}{l}\text { Evan starts his sentence in German } \\
\text { and includes English and completes } \\
\text { the sentence in German }\end{array}$ \\
\hline $\begin{array}{l}\text { N: Sechs Uhr } \\
\text { fünfundfünfzig }\end{array}$ & Six o'clock fifty five & \\
\hline M: Wie viel Uhr ist es? & What time is it? & \\
\hline $\begin{array}{l}\text { V: Es ist siebzehn Uhr } \\
\text { zwanzig. Wie viel Uhr ist } \\
\text { es? }\end{array}$ & $\begin{array}{l}\text { It is seventeen } \\
\text { o'clock twenty. What } \\
\text { time is it? }\end{array}$ & \\
\hline E: Es ist drei thirtynine & It is three thirtynine & $\begin{array}{l}\text { Evan starts in German and uses the } \\
\text { English numbers because he is not } \\
\text { sure how to read time in German }\end{array}$ \\
\hline $\begin{array}{l}\mathrm{N} \text { : You put the last } \\
\text { number first and then you } \\
\text { say let's say }\end{array}$ & & $\begin{array}{l}\text { Nico gives an explanation of how to } \\
\text { read the numbers }\end{array}$ \\
\hline $\begin{array}{l}\text { E: Es ist zwanzig nach } \\
\text { drei }\end{array}$ & It is twenty past three & $\begin{array}{l}\text { Evan is using German to read the } \\
\text { time correctly }\end{array}$ \\
\hline
\end{tabular}

Quejona is a German heritage language learner who is exclusively using German in the class. At her home both German and English are spoken. Her 
grandma is from Germany and has traveled to Germany often. The excerpt below is from a class activity in which modal verbs were practiced. In the conversation below I asked her for something that she must do and for something that she would like to do, so that the rest of the class could hear an example for each of the two modal verbs.

Table 7. Excerpt 7 In-class Conversation

\begin{tabular}{|c|c|c|}
\hline Utterance & $\begin{array}{c}\text { English } \\
\text { Translation }\end{array}$ & Explanation \\
\hline $\begin{array}{l}\text { A: Und du? Was } \\
\text { sollst du machen? }\end{array}$ & $\begin{array}{l}\text { And you? What } \\
\text { are you supposed } \\
\text { to do? }\end{array}$ & $\begin{array}{l}\text { Modeling modal verbs use in a question for } \\
\text { the rest of the class }\end{array}$ \\
\hline $\begin{array}{l}\text { Q: Ich soll nächsten } \\
\text { Samstag zur Arbeit } \\
\text { gehen. }\end{array}$ & $\begin{array}{l}\text { I'm supposed to } \\
\text { go to work next } \\
\text { Saturday. }\end{array}$ & \\
\hline $\begin{array}{l}\text { A: Was möchtest du } \\
\text { machen? }\end{array}$ & $\begin{array}{l}\text { What would you } \\
\text { like to do? }\end{array}$ & \\
\hline $\begin{array}{l}\text { Q: Ich möchte } \\
\text { wieder heim gehen } \\
\text { nach Deutschland. }\end{array}$ & $\begin{array}{l}\text { I would like to go } \\
\text { back home to } \\
\text { Germany. }\end{array}$ & $\begin{array}{l}\text { When asked what she would like to do, } \\
\text { Quejona gave this example thereby showing } \\
\text { that she still has strong ties to Germany and } \\
\text { she considers it to be her home, as she } \\
\text { explained during her interviews }\end{array}$ \\
\hline A: Okay. & & \\
\hline
\end{tabular}

\section{Discussion}

The goal of this case study was to find out how bilingual learners are making sense out of learning German, and it can be said that a translanguaging pedagogy was useful in creating a classroom environment that was conducive to learning. Similarly to other translanguaging research this study shows translanguaging as a successful strategy to promote language acquisition and as a strategy to integrate and include students (Hornberger \& Link, 2012; Collins \& Cioé-Peña, 2016; Makalela, 2015). Collins \& Cioé-Peña (2016) describe that through multilingual collaborative group work emergent bilingual students are given the opportunity to translanguage, which contributes to the development of a more assertive identity, which could also be noticed with the participants in this study. Translanguaging can contribute to both the empowering of students and to their development of self-confidence. Students in this study demonstrated a deep understanding of the new content they were learning. They used translanguaging to include other students, demonstrate their knowledge and co-construct meaning and mediate understanding among each other (Garcia \& Wei, 2014, p. 82).

Claudia, Lino, Adrian, Carlos, Iskra, Stephanie, Andre and Humberto all participated in either bilingual or dual language programs throughout their educational journey and identified as bilingual. Of this group Iskra and Adrian went to a school that was even emphasizing a third language in addition to English and Spanish they took German from Kinder until $8^{\text {th }}$ grade. Claudia finished high 
school in Ecuador. Lino had been going to school in Brazil and speaks Portuguese in addition to Spanish and English. Humberto went to a middle school and later high school serving students with low-socio economic status at the border, in a school district that was affected by a testing scandal (Reyes, 2016). Creating a classroom atmosphere in which all students feel validated and respected regardless of what languages they speak or what socio-economic background they have is an important foundation to facilitate the learning process of learning an additional language. As a participant of the study and the instructor of the German classes I would model translanguaging as a strategy for learning by opening the classroom space for social interactions and peer grouping students according to their language repertoire encouraging collaborative dialogue (Garcia, Ibarra-Johnson, \& Seltzer, 2017). As the instructor I do not monopolize the classroom time with lengthy explanations of how language concepts work, but rather students try out new concepts after seeing them modeled. Furthermore, students know that they can rely on their group members for help and explanations as well as on my feedback as I circle around the classroom interacting with groups.

The time in class is organized around interactions, while interactions in a language class can be artificial or constructed, I aim to get to know students well so I can ask them questions regarding their life and interests to create an authentic exchange. As a German person I share my culture with my students in the classroom but also through inviting them to explore and make connections with the local German community. For example, I share German holidays with students through celebrations in the community, but I also make connections to the local culture by celebrating holidays such as Dia de los Muertos. Making authentic connections to the students' knowledge and their cultural backgrounds builds trust and opens up the space for learning. Translanguaging as an approach "recognizes the complexity of people's everyday spaces and multiple resources to make sense of the world" (Garcia \& Wei, 2014, p. 24). Participants of this study used translanguaging to make sense of German (Garcia \& Wei, 2014)

A limitation of the study is that I am the researcher and also particpant of the study so my double role might have influenced the participants. However, all participants had volunteered to parttake in this study and had the option to dicontinue the study at any point. All participants remained in the study. Participants gave positive feedback that they were enjoying being part of this research process and that the topic and research focus was meaningful to them. Students seemed genuienly excited to share about themselves during the interview process. Students also took an active role throughout the research guiding the discussions addressing whichever topic they felt was important to them one example for that is Excerpt 4. All participants were in control of their recording devices while in the class. Furthermore, a member check took place every participant was able to see their transcribed conversations and was able to give their perspective. Through this process data was triangulated thereby giving control to the participants. Althouhg this study was conducted during one semester due to the fact that I have a double role of researcher and participants I was able to follow the same group of students over the course of two years and have first hand insight into how their German language developed over the course of time. 
Therefore a longitudional study might be useful to show how a translanguaging pedagogy can assist language development.

\section{Conclusions}

The German classes at a borderland university that were at the heart of this qualitative study highlight the intersectionality of language use, language identity, and ideology. Deficit discourses have influenced the participants of this study, consequently the Mexican-American students in this case study were feeling selfconscious about using Spanish to make sense of German, in a classroom setting with Mexican students who speak Spanish at home and have been educated in Mexico. The transfronterizo students who cross the border on a regular basis were adjusting their language use to their interlocutors, but spoke Spanish exclusively among themselves. They did not favor a perceived mixing of the two languages English and Spanish, which they described as a common practice taking place on the American side of the border. Ultimately learning German through a translanguaging pedagogy was a catalyst of becoming more aware of language ideologies that have previously not been reflected on. Translanguaging can contribute to decolonizing notions of language purism. As Razfar \& Rumenapp (2012) show in their study making language ideologies explicit can open space to question and counter them. Participants in this study verbalized language ideologies thereby allowing a process of reflection on them. Through their respective language choices participants portrayed their language identity which is underpinned by notions of language identity. According to Garcia and Sylvan (2011) it is possible to overcome monolingual language ideologies through translanguaging. In the case of this study the monolingual language ideologies were uncovered and reflected on; however, using a translanguaging pedagogy alone is only slowly changing those long-held believes students bring to the classroom. Particularly if they have been acquired over a long period of time. What seemed to be powerful for the participants of this study and motivated them to participate was the fact that I have a genuine interest in their backgrounds and culture and family heritage and knowledge that I demonstrate every day through interactions in the classroom. Similarly, to Rios (2013) study students' knowledge was made visible trough the interactive work in the classroom. Learning German allowed that space of reflection on dominant language discourses. As Anzaldua (1987) states students can learn to become conscious of those discourses. The translanguaging classroom can thereby become a space without linguistic, national and cultural borders a space for transformation (Garcia \& Wei, 2014, p.43).

Future research can investigate that potential for decolonization of knowledge and identities. Through translanguaging practices it became visible that one utterance can represent "the juxtaposition and intermixing of two different and potentially conflicting worldviews, styles, social languages, accents, or voices" (Cervantes-Soon \& Carrillo, 2016, p. 290). 


\section{References}

Abraham, S. (2014). A nepantla pedagogy: comparing Anzaldua's and Bakhtin's ideas for pedagogical and social change. Critical Education, 5(5), 1-20.

Abrams, Z. (2016). Exploring collaboratively written L2 texts among first-year learners of German in Google Docs. Computer assisted language learning, 29(8), 1259-1270.

Anzaldúa, G. (1987). Borderlands/La frontera: The new mestiza. San Francisco: Aunt Lute Books.

Aslan, E. (2015). When the native is also a non-native: "retrodicting" the complexity of language teacher cognition. The Canadian modern language review, 71(3), 244-269.

Bakhtin, M. (1981). The dialogic imagination: Four essays. Austin: University of Texas Press.

Bartolotti, J., \& Marian, V. (2017). Bilinguals' existing languages benefit vocabulary learning in a third language. Language learning, 67(1), 110-140.

Belz, J.A., \& Reinhardt, J. (2004). Aspects of advanced foreign language proficiency: Internet-mediated German language play. International Journal of Applied Linguistics, 14(3), 324-362.

Bono, M., \& Stratilaki, S. (2009). The M-factor, a bilingual asset for plurilinguals? Learners' representations, discourse strategies and third language acquisition in institutional contexts. International Journal of Multilingualism, 6(2), 207-227.

Carrillo, J. (2013). I always knew I was gifted: Latino males and the Mesitz@ theory of intelligences (MTI). Berkely Review of Education, 4(13), 70-95.

Cashman, T.G. (2015). Developing a critical border dialogism: Learning from fellow educators in Malaysia, Mexico, and Canada. Charlotte, NC: Information Age.

Cashman, T.G. (2016). Critical border praxis: Choosing the path of critical border dialogism. Critical Education, 7(1), 1-15.

Cenoz, J., \& Gorter, D. (2011). A holistic approach to multilingual education: introduction. The Modern Language Journal, 95(3), 339-343.

Cervantes-Soon, C.G., \& Carillo, J.F. (2016). Toward a pedagogy of border thinking: Building on Latin@ students' subaltern knowledge. The High School Journal, 99(4), 282-301.

Collins, B.A., \& Cioe-Peña, M. (2016). Translanguaging in the social studies classroom to understand complex texts. In O. García, \& T. Kleyn, Translanguaging with Multilingual Students: Learning from Classroom Moments. London: GB: Routledge.

Creese, A., \& Blackledge, A. (2010). Translanguaging in the bilingual classroom: a pedagogy for learning and teaching. The Modern Language Journal, 94(1), 103-115.

Creswell, J. (2005). Educational research. Planning, conducting and evaluating quantitative and qualitative research $\left(2^{\text {nd }}\right)$. Upper Saddle River, NJ: Pearson Education.

De Angelis, G. (2007). Third or additional language acquisition. Clevedon, UK: Multilingual Matters.

De Angelis, G. (2011). Teachers' beliefs about the role of prior language knowledge in learning and how these influence teaching practices. International Journal of Multilingualism, 8(3), 216-234.

Di Donato, R.C. (2004). Deutsch: Na klar!: An introductory German course. McGrawHill.

De Oliveira Santos, V.D. (2015). Can colors, voices, and images help learners acquire the grammatical gender of German nouns? Language Teaching Research, 19(4), 473498. 
Dixon, E., \& Hondo, J. (2013). Re-purposing an OER for the online language course: a case study of Deutsch interaktiv by the Deutsche Welle. Computer assisted language learning, 27(2), 109-121.

Esquinca, A. (2013). A transfronteriza pre-service teacher managing, resisiting, and coping with the demands of mathematical discourse. International journal of qualitative studies in Education, 26(3), 279-300.

Esquinca, A., Araujo, B., \& de la Piedra, M. (2014). Meaning making and translanguaging in a two-way dual language program on the U.S.-Mexico Border. Bilingual Research Journal, 37(2), 164-181.

Falk, Y., \& Bardel, C. (2010). The study of the role of the background languages in third language acquisition. IRAL, 48(2-3), 185-219.

Freire, P. (1970). Pedagogy of the oppressed. New York: Herder and Herder.

García, O. (2009). Bilingualism and translanguaging. In O. García (ed.), Bilingual education in the 21 st century: A global perspective (pp. 42-72). Malden, MA: WileyBlackwell.

García, O. (2014). Countering the dual: Transglossia, dynamic bilingualism and translanguaging in education. In R. Ruby, L. Alsagoff (eds) The global-local interface, language choice and hybridity (pp. 100-118). Bristol: Multilingual Matters.

García, O. \& Leiva, C. (2014). Theorizing and enacting translanguaging for social justice. In: A. Blackledge, Heteroglossia as practice and pedagogy (pp. 199-216). Netherlands: Springer.

García, O., \& Sylvan, C. (2011). Pedagogies and practices in multilingual classrooms: Singularities in pluralities. The Modern Language Journal, 95(3), 85-400.

García, O., \& Wei, L. (2014). Translanguaging. New York: Palgrave Macmillan.

García, O., Homonoff Woodley, H., Flores, N., \& Chu. (2012). Latino emergent bilingual youth in high schools: transcaring strategies for academic success. Urban education, 46(6), 798-827.

Garcia, O., Ibarra-Johnson, S. \& Seltzer, K. (2017). The translanguaging classroom: Leveraging student bilingualism for learning. Philadelphia: Caslon.

Ghanem, C. (2015). Teaching in the foreign language classroom: How being a native or non-native speaker of German influences culture teaching. Language teaching Research, 19(2), 169-186.

Gonglewski, M.M. (2013). Treffpunkt Deutsch Grundstufe.Pearson.

Grenfell, M., \& Harris, V. (2015). Learning a third language: What learner strategies do bilingual students bring? J. Curriculum Studies, 47(4), 553-576.

Grosjean, F. (2010). Bilingual: Life and reality. Cambridge, MA: Havard University Press.

Hansen-Thomas, H. (2007). Language ideology, citizenship, and identity. Journal of Language and Politics, 6(2), 249-264.

Hornberger, N. (2002). Multilingual language policies and the continua of biliteracy: An ecological approach. Language Policy, 1(1), 27-51.

Hornberger, N., \& Link, H. (2012). Translanguaging and transnational literacies in multilingual classrooms: A bilingual lens. International Journal of Bilingual Education and Bilingualism, 15(3), 261-278.

Jackson, C.N. (2007). The use and non-use of semantic information, word order, and case markings during comprehension by L2 learners of German. The Modern Language Journal, 91(3), 418-432.

Jaensch, C. (2011). L3 acquisition of German adjectival inflection: A generative account. Second Language Research, 27(1), 83-106.

Jessner, U. (2008). Teaching third languages: Findings, trends and challenges. Language Teaching, 4l(1), 15-56. 
Lewis, G., Jones, B., \& Baker, C. (2012). Translanguaging: origins and development from school to street and beyond. Educational Research and Evaluation, 18(7), 641-654.

Lichtman, M. (2013). Qualitative research in education: A user's guide (3rd ed.). Thousand Oaks, CA: Sage Publications.

Lopez, M.H. (2013), September 5. What is the future of Spanish in the United States? Retrieved from https://pewrsr.ch/2Oh23gi.

Makalela, L. (2015). Moving out of linguistics boxes: the effects of translanguaging strategies for multilingual classrooms. Language and Education, 29(3), 200-217.

Mazak, C.M., \& Herbas-Donoso, C. (2015). Translanguaging practices at a bilingual university: a case study of a science classroom. International Journal of Bilingual Education and Bilingualism, 18(6), 698-714.

Melo-Pfeifer, S. (2015). Translanguaging. Language, bilingualism and education. Language and intercultural communication, 15(1), 179-181.

Neville, D.O., Shelton, B.E., \& McInnis B. (2009). Cybertext redux: using digital gamebased learning to teach L2 vocabulary, reading, and culture. Computer Assisted Language Learning, 22(5), 409-424.

Ramirez, P. C., Ross, L., and Jimenez-Silva, M. (2016). The intersectionality of border pedagogy and Latina/o youth: Enacting border pedagogy in multiple spaces. The High School Journal, pp. 302-321.

Reyes, R. (2016). In a world of disposable students: The humanizing elements of border pedagogy in teacher education. The High School Journal, 99(4), 337-350.

Rios, C. (2013). A curriculum of the borderland: High school Chicano/a Latina studies as sitios y lengua. The Urban Review, 45(1), 58-73.

Rothman, J., Iverson, M., \& Jurdy, T. (2010). Introduction: some notes on the generative study of L3 acquisition. Second language research, 27(1), 5-19.

Razfar, A., \& Rumenapp, J. (2012). Language ideologies in English learner classrooms: critical reflection and the role of explicit awareness. Language Awareness, 21(4), 347-368.

Salinas, C., Vuckery, A., \& Franquiz, M. (2016). Advancing border pedagogies: Understanding of citizenship through comparisons of home to school contexts. The High School Journal, 99(4), 322-336.

Scheutz, M.J., \& Eberhardt, K.M. (2004). Effects of morphosyntactic gender features in bilingual language processing. Cognitive Science, 28, 559-588.

Schmid, M.S. (2014). The debate on maturational constraints in bilingual development: A perspective from first-language attrition. Language Acquisition, 21(4), 386-410.

Schieffelin, B., Woolard, K.A., \& Kroskrity, P. (1998). Language ideologies: Practice and theory. New York: Oxford University Press.

Seidman, I. (2013). Interviewing as qualitative research: a guide for researchers in education and the social sciences. NY: Teachers College Press.

Sembiante, S. (2016). Translanguaging and the multilingual turn: epistemological reconceptualization in the fields of language and implications for reframing language in curriculum studies. Curriculum Inquiry, 46(1), 45-61.

Stewart, K., \& Gachego, D. (2016). Being human today: A digital storytelling pedagogy for transcontinental border crossing. British Journal of Education Technology, 47(3), 528-542.

Tschirner, E.N. (2017). Kontakte. McGraw-Hill.

Turkan, S., \& DaSilva Iddings, A.C. (2012). That child is a yellow: New immigrant children's conceptions of English language, literacy, and learners' identities in the NCLB era. Theory into Practice, 51(4), 273-280.

U.S. Department of Education. (2015). Digest of education statistics. National Center for Education Statistics. Retrieved from https://bit.ly/2RlbDRd. 
Ullman, C. (2012). 'Before I didn't understand anything about white people, but now, I speak English': negotiating globally mediated discourses of race, language, and nation. Discourse: Studies in the cultural politics of education, 33(2), 251-266.

UTEP. (2017, November 28). About UTEP. Retrieved from https://bit.ly/2CRjIcb.

Valenzuela, A. (1999). Subtractive schooling: U.S. Mexican youth and the politics of caring. Albany, NY: SUNY Press.

Velasco, P., \& García, O. (2014). Translanguaging and the writing of bilingual learners. Bilingual Research Journal, 37(1), 6-23.

Veltkamp, G., Recio, G., Jacobs, A.M., \& Conrad, M. (2012). Is personality modulated by language? Bilingualism, 17(4), 496-504.

Weninger, C. (2007). Speakers' perception of code choice in a foreign language academic department. Journal of Multilingual and Multicultural Development, 28(2), 134-151.

Wilson, C., Ek, L., Ty, M., and Douglas, M. (2014). Recasting border crossing politics and pedagogies to combat educational inequality. The Urban Review, 46(1), 1-24.

Woolard, K. (1992). Language ideology: Issues and approaches. Pragmatics, 2(3), 235249.

Zentella, A.C. (2007). Dime con quién hablas y te dire quién eres: Linguistic (In)security and Latino Unity. In J. Flores, R. Rosaldo, (Eds.) The Blackwell companion to Latino Studies (pp. 25-39). Malden, MA: Blackwell. 